\title{
KEBIJAKAN PENGKARYAAN KEMBALI PEKERJA SENIOR JEPANG PASCA PENSIUN (SUDUT PANDANG PERUSAHAAN MANUFAKTUR)
}

\author{
Dewi Saraswati Sakariah \\ Program Studi Bahasa dan Sastra Jepang, Universitas Diponegoro, \\ Jl. Prof. Soedarto, SH, Kampus Undip Tembalang, Semarang, Indonesia 50275
}

\begin{abstract}
Abstrak
Penelitian ini membahas fenomena pengkaryaan kembali pekerja senior pasca pensiun di perusahaan menufaktur Jepang. Jepang yang merupakan negara dengan penuaan populasi tercepat no 1 di dunia mengalami masalah dalam demografi penududuknya. Sementara itu, pemerintah semakin gencar melancarkan upaya-upaya untuk membuat Jepang bangkit dari resesi ekonominya sejak tahun 1990-an. Salah satunya adalah menghimbau setiap dari masyarakat yang masih mampu bekerja untuk berkontribusi pada sektor ketenagakerjaan demi tercapainya strategi pertumbuhan ekonomi. Salah satu kelompok yang didorong adalah pekerja senior pasca pensiun pada perusahaan manufaktur Jepang. Himbauan tersebut disambut baik dengan mulai banyaknya perusahaan yang mengadopsi sistem tersebut dengan berbagai alasan, yakni angka harapan hidup yang meningkat, adanya himbauan pemerintah kepada masyarakat, kebutuhan perusahaan akan pekerja senior yakni produktivitas dan transfer keahlian, gaji dan pandangan perusahaan terhadap pekerja muda. Penelitian ini akan dilihat dari perspektif perubahan sosial dalam masyarakat Anthony Giddens. Penelitian ini menyimpulkan bahwa fenomena pengkaryaan kembali pekerja senior pasca pensiun merupakan akibat dari perubahan-perubahan sosial yang terjadi dalam masyarakat Jepang saat ini. $p E$
\end{abstract}

Kata kunci: pengkaryaan kembali, pekerja senior, manufaktur Jepang

\begin{abstract}
This study discusses about the phenomenon of the re-employed senior workers after retirement in Japan's manufacturing companies. Japan is a country with the fastest aging population in the world that has many problems in itspopulation demographic.Meanwhile, the government launched intensifying efforts to make Japan rises from its economic recession since the 1990s. One of the efforts is call on each of the people who is still able to work to contribute to the employment sector in order to achieve economic growth strategy. One of the encouraged groups isthe post-retirementsenior workers in Japan's manufacturing companies.The call on was well received while a number of companies were adopting this system with several different reasonsnamely life expectancy increases, the government calls to the people, the needs of the company's senior workers for productivity and skill transfering, the salary and the company's view of the young workers. This research will be interpreted by sosial changes perspective in society from Anthony Giidens. This study concludes that the phenomenon of the re-employed senior workers after retirement is the result of social changes that has occurred in Japanese society today.
\end{abstract}

Keywords: senior workers, re-employment, manufacturing

${ }^{*}$ Penulis Korespondensi.

E-mail: sarasdewiq@gmail.com

\section{Pendahuluan}

Pada tahun 2012 pasca terpilihnya Shinzo Abe untuk kedua kalinya sebagai perdana menteri, kebijakan abenomics dikeluarkan. Salah satu arah kebijakan abenomics adalah menyorot potensi para pekerja yang telah pensiun agar diberikan

peluang untuk dikaryakan kembali. Hal ini dilakukan dengan pertimbangan bahwa masalah kekurangan tenaga kerja yang dialami Jepang saat ini membuat pekerja senior ${ }^{1}$ memegang peran kunci terhadap masa depan ekonomi Jepang. Jika

\footnotetext{
1 Istilah 'Pekerja Senior' merupakan istilah yang dipakai penulis dalam penelitian ini untuk menyebut pekerja yang berada dalam usia 60 tahun dan 60 tahun ke atas yang telah memasuki usia wajib pensiun.
} 
kekurangan tenaga kerja dari kelompok usia muda dan usia pertengahan muncul sebagai hasil dari turunnya angka kelahiran, maka pertumbuhan ekonomi Jepang akan banyak bergantung pada pekerja senior mereka. ${ }^{2}$ oleh karena itu pekerja senior diharapkan dapat tetap mengisi sektor ketenagakerjaan Jepang di kemudian hari. Kemampuan untuk mendukung kelompok pekerja senior ini bergantung pada cara pemerintah mempertahankan angka partisipasi pekerja senior di sektor ketenagakerjaan. (Matsukura dkk :2008).

Hingga pada bulan April tahun 2013 lalu, akhirnya pemerintah Jepang memberlakukan hasil keputusan revisi tahun 2012 yang menghimbauan perpanjangan usia untuk bekerja setelah melewati usia 60 tahun jika masih terdapat kemauan untuk bekerja bagi pekerja senior yang telah pensiun, sehingga mereka yang telah pensiun masih diberi kesempatan untuk tetap bekerja di perusahaan hingga di usia 65 tahun. Berdasarkan revisi tersebut pemerintah berencana menetapkan wajib pensiun di usia 65 tahun pada tahun 2025 yang akan datang di seluruh perusahaan Jepang.

Dari pernyataan tersebut, kebijakan pemerintah Jepang ini tentu tidak dapat berjalan jika tidak ada dukungan dari pihakpihak yang berkaitan dengan revisi pemerintah itu yakni pihak perusahaan dan pekerjanya sendiri. Meski kebijakan pemerintah di atas bersifat himbauan, terlepas dari itu keputusan final ada di pihak perusahaan sebagai tuan pemberi kerja untuk memutuskan apakah mereka akan mengkaryakan kembali pekerja senior mereka setelah pensiun atau tidak.

\section{Permasalahan}

Kebijakan mengenai pekerja tidak pernah terlepas dari lingkup tempat ia bekerja. Kebijakan abenomics yang dikeluarkan oleh pemerintah Jepang tidak hanya melibatkan penguasa dan pekerjanya saja, namun pihak penting lain yang terlibat adalah pihak pemberi kerja, yakni perusahaan Jepang (manufaktur). Kebijakan pemerintah tidak akan berjalan dengan baik tanpa dukungan pihak perusahaan. Karena itu bertahun-tahun sebelumnya sosialisasi mengenai kebijakan pengkaryaan kembali pekerja senior terus dilakukan. Penelitian ini akan melihat pandangan dari sisi perusahaan manufaktur Jepang apakah mendukung atau tidak pengkaryaan kembali pekerja mereka yang telah pensiun.

\section{Pembahasan}

\subsection{Perusahaan manufaktur Jepang}

Manufaktur adalah proses konversi bahan baku, komponen atau bagian lain menjadi barang jadi yang memenuhi harapan atau spesifikasipelanggan. Sedangkan perusahaan manufaktur adalah perusahaan yang bekerja di bidang tersebut seperti perusahaan tekstil, makanan, ataupun kendaraan. Perusahaan manufaktur umumnya mempekerjakan manusia maupun mesin dengan pembagian kerja dalam produksi skala besar. Setelah pecahnya gelembung ekonomi di tahun 1990an yang ditandai dengan masifnya peristiwa kolaps yang dialami oleh pasar saham dan real estate, perusahaan-perusahaan besar ditekan untuk merestruktur dirinya dan sistem kerja jangka panjang yang dianggap tradisi saat itu mulai menghilang. Meski begitu, sektor industri manufaktur di Jepang tetap memiliki banyak perusahaan-perusahaan dan industri-industri dengan teknologi kelas dunia yang dimanjakan oleh kebijakan-kebijakan protektif dari pemerintah karena saat itu banyak orang yang percaya bahwa perusahaan-perusahaan non manufaktur tidak bisa merealisasikan tipe pertumbuhan produktifitas sekuat sektor manufaktur, karena pada masa pertumbuhan ekonomi yang tinggi angka produktivitas sektor manufaktur melebihi sektor agrikultur ataupun jenis sektor lain yang mengandalkan cara kerja tradisional. Perusahaan-perusahaan manufaktur pada masa itu gencar mengarahkan dirinya untuk berkompetisi pada inovasi teknologi dan perdagangan internasional bahkan ketika pada masa gelembung ekonomi terdapat rencana 
relokasi ke negara-negara lain karena nilai yen yang tinggi, beberapa dari mereka tetap berkompetisi dengan perusahaan-perusahaan jasa real estate, konstruksi dan jasa yang pada waktu itu sedang mengalami penggelembungan nilai meski kurang efisien.

Hal ini menjelaskan bahwa sektor industri manufaktur menempati posisi penting dalam pertumbuhan ekonomi Jepang sehingga pemerintah melindungi sektor tersebut.Berdasarkan presentasi dari METI, MHLW dan MEXT, saat ini harga saham meningkat dan keuntungan perusahaan membaik serta terdapat sinyal yang berkembang menuju peningkatan upah (tren menuju siklus ekonomi yang baik), tidak hanya itu di sisi lain perusahaan-perusahaan kecil dan menengah juga mulai terlihat perkembangannya. Ini merupakan efek positif dari abenomics yang telah menyerap ke dalam industri manufaktur Jepangyang sejak lama ditekan untuk berkompetitif secara sengit satu sama lain.

Kawaguchi (2013) dalam penelitiannya mengatakan bahwa menurut sensus nasional yang dilakukan oleh Departemen Dalam Negeri dan Komunikasi, jumlah karyawan di industri manufaktur Jepang adalah sekitar 14,6 juta pada tahun 1990, dan menurun menjadi kurang dari 10 juta, sekitar 9,6 juta, pada tahun 2010. Sementara itu Total kerja menurun dari sekitar 24\% pada tahun 1990 menjadi sekitar $16 \%$ pada tahun 2010 .

Grafik:Persentasi jumlah pekerja pada industri manufaktur Jepang tahun 1975-2010.

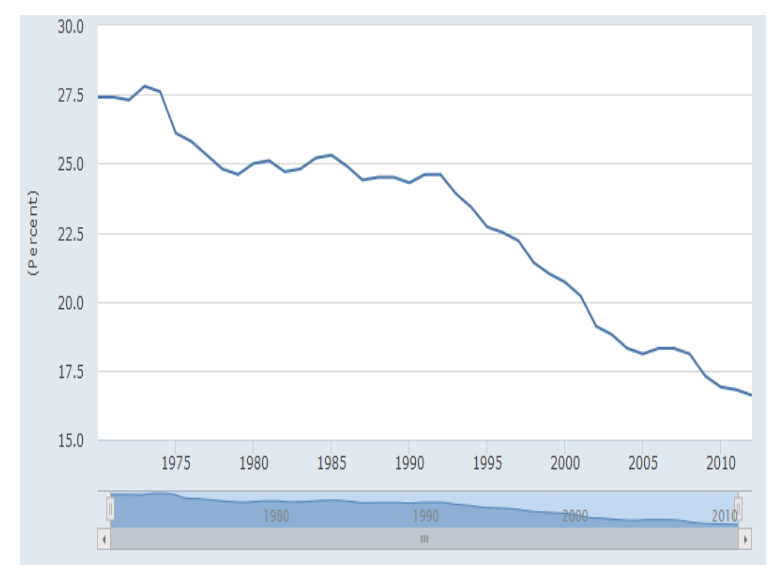

Sementara fluktuasi kurs mata uang asing mempengaruhi jumlah karyawan di industri manufaktur dalam jangka pendek, selanjutnya, mengingat produktivitas tenaga kerja di Timur dan negara-negara Asia Tenggara meningkat karena mereka berkembang pula dalam teknologi, produk industri murah berkualitas tinggi telah memasuki pasar Jepang. Dengan masuknya produk industri asing dan peningkatan produktivitas perusahaandalam negeri, jumlah karyawan di industri manufaktur pasti menurun.Selain itu, dalam rangka untuk bersaing dengan produk industri dari luar negeri, produk industri dalam negeridiproduksi terbatas kepada mereka yang membutuhkan. Akibatnya, produktivitas tenaga kerja di industri manufaktur dalam negeri lebih ditingkatkan, yang mengarah ke peningkatan produktivitas tenaga kerja di industri manufaktur dan penurunan bersamaan dalam pekerjaan.

\subsection{Pandangan manufaktur Jepang terhadap pengkaryaan kembali pekerja pasca pensiun.}

Dikaryakannya kembali pekerja senior meski telah mencapai usia pensiun didorong oleh faktor-faktor tertentu dari pihak-pihak yang terkait di dalamnya,dalam hal ini khususnya melihat pihak perusahaan dan pekerja senior sektor manufaktur di Jepang. Pada penelitian ini penulis ingin menggali lebih dalam mengenai pengkaryaan kembali para pekerja senior tersebut pasca pensiun dari sisi pandangan perusahaan dan pekerja senior pasca pensiun itu sendiri.

\section{1) Meningkatnya angka harapan hidup.}

Saat ini angka harapan hidup rata-rata penduduk di Jepang telah meningkatdari tahun ke tahun mengikuti taraf hidup masyarakatnya yang semakin baik. Hal tersebut membuat laju penuaan populasi Jepang menempati urutan no 1 di seluruh dunia. 
Tersedia online di http://ejournal.undip.ac.id/index.php/izumi

Menurut KY yang bekerja sebagai Presiden Direktur di salah satu perusahaan manufaktur Jepang mengungkapkan bahwa terdapat beberapa alasan mengapa perusahaannya memutuskan untuk mengkaryakan pekerja senior mereka meski telah mencapai usia pensiun. Simak pernyataan KY berikut ini:

"....Saya pikir terdapat 2 alasan besar, alasan pertama adalah rata-rata usia orang Jepang saat ini adalah 80 tahun. Jadi jika seseorang pensiun di usia 60 tahun mereka (masih) memiliki waktu 20 tahun, dan itu adalah waktu yang panjang. Dulu, usia 60 tahun adalah seseorang yang sangat tua, tapi saat ini di Jepang usia tersebut masih muda dan sangat sehat, sebagaimana yang saya katakan kepada anda bahwa ratarata usia orang Jepang adalah 80 tahun..."

KY melanjutkan bahwa:

"...Mereka masih memiliki semangat dan keinginan untuk bekerja, oleh karena itu perusahaan kami memutuskan untk merekrut orang yang cerdas hingga umur 65 tahun. Dan alasan lain seperti yang anda katakan tadi bahwa mereka masih sehat, masih baik (kondisi) dan memiliki semangat untuk bekerja keras. Dan bagi kami itu hal yang bagus..."

Kembali pada KY, bagi perusahaannya, meski memutuskan untuk mengkaryakan kembali pekerja seniornya tidak serta merta dilakukan begitu saja pada semua pekerjanya, tetapi mereka memiliki syarat khusus yakni memilih dan mengkaryakan kembali pekerja senior yang dinilai cerdas oleh mereka.

Pekerja senior pasca pensiun yang berinisial DLini mengatakan bahwa:

"Selama pegawai tersebut masih sehat, ada kemauan, dan perusahaan sendiri mengijinkannya, pegawai tersebut masih bisa bekerja sampai usia 65 tahun."
Adanya perubahan usia yang semakin panjang menunjukkan bahwa masyarakat Jepang memiliki waktu hidup yang panjang dengan kondisi kesehatan yang kualitasnya baik sehingga mereka juga memiliki kondisi fisik yang rata-rata masih sehatdi usia 60 tahun mereka. Hal ini mengubah pandangan umum bahwa seseorang dengan usia 60 tahun yang dulunya dipandang tua kini dilihat sebagai usia yang masih muda dan masih mampu bekerja bagi masyarakat Jepang saat ini.

\section{2) Himbauan pemerintah Jepang kepada masyarakat}

Pada tahun 2013 lalu, pemerntah telah merevisi sebagian Undnag-Undang mengenai tindakan stabilisasi ketenagakerjaan pekerja senior yang bertujuan menyediakan lingkungan di mana pekerja senior dapat terus bekerja sesuai dengan motivasi dan kemampuan mereka masing-masing, setidaknya sampai usia di mana mereka dapat mulai menerima uang pensiun. Untuk itu, pemerintah menghimbau kepada perusahaan-perusahaan Jepang untuk mengkaryakan kembali pekerja senior pasca pensiun di perusahaannya. Kebijakan ini mendorong banyak perusahaan untuk mencoba mengkaryakan kembali pekerja seniornya sehingga rencana pemerintah untuk mewajibkan usia pensiun pada usia 65 pada tahun 2050 dapat terlaksana.

Simak hasil wawancara bersama DL di bawah ini:

"Saat ini, ada kebijakan pemerintah untuk mengkaryakan kembali pekerja di sebagian besar perusahaan Jepang, khususnya bagi perusahaan yang sudah melampaui skala besar tertentu. Latar belakang dari kebijakan tersebut adalah, dikarenakan masalah asuransi, pekerja berhak menerima asuransi ketenagakerjaan. Selama ini pegawai berhak menerima asuransi tersebut saat umur 60 tahun, namun sekarang sudah berubah menjadi 65 tahun. Bisa dibilang lama usia untuk mendapat asuransi tersebut semakin 
bertambah ya. Di lain pihak, dari pemerintah sendiri ada himbauan agar perusahaan tetap mempekerjakan pegawainya sampai usia 65 tahun, sehingga sebagian besar perusahaan ternama yang tadinya memberlakukan usia pensiunnya 60 tahun, lama kelamaan mengubahnya jadi 65 tahun. Selama pegawai tersebut masih sehat, ada kemauan, dan perusahaan sendiri mengijinkannya, pegawai tersebut masih bisa bekerja sampai usia 65 tahun."

Berikut wawancara lanjutan dengan DL:

$$
\text { "Kalau ditanya kenapa }
$$
kebijakan itu bisa diberlakukan, seperti yang sudah saya katakan sebelumnya, karena kalau tidak, sang pensiun jadi tidak bisa memenuhi kebutuhan hidup. Kebijakan negara untuk memberi dana pensiun seperti asuransi, dana kesejahteraan, dan dana pensiun lainnya, saat ini berlaku apabila berusia 65 tahun. Kalau misalkan saat berusia 60 sudah diberhentikan oleh perusahaan, tentu saja ia jadi tidak bisa memenuhi kehidupan sehari-hari ke depannya. Dulu, apabila seseorang sudah berusia 60, ia sudah bisa mendapat dana pensiun tersebut, sehingga walau pensiun di usia 60 , pensiunan tetap menerima pemasukan secara berkelanjutan. Tapi kalau sekarang, sebelum berusia 65, tidak bisa mendapat dana pensiun tadi, sehingga selama 5 tahun, pensiunan jadi tidak dapat pemasukan apa-apa."

Adanya kondisi yang cukup genting yang dapat terjadi jika para pekerja harus menunggu selama 5 tahun untuk memperoleh uang pensiunnya membuat pemerintah harus mencari jalan keluar agar para pekerja tersebut dapat tetap menjalankan hidup dengan tetap memiliki pemasukan. Maka dari itu pemerintah Jepang memilih menghimbau perusahaan untuk mengkaryakan kembali pekerjanya pasca pensiun setidaknya sampai pada usia mereka dapat menerima uang pensiun. Adapun kebijakan yang dihimbaukan oleh pemerintah Jepang merupakan kebijakan yang tidak pukul rata mewajibkan seluruh perusahaan untuk mengkaryakan kembali perusahaannya. Himbauan ini hanya ditegaskan pada perusahaan-perusahaan yang mampu saja, seperti pada perusahaan DL, DS dan DT.

"Oleh karenanya, tentu saja perusahaan kecil belum mampu untuk menerapkan kebijakan seperti itu. Meskipun ada beberapa perusahaan yang tergolong sulit untuk menerapkan kebijakan tadi, lain ceritanya kalau perusahaannya sekelas Hino Jidousha (kendaraan). Saya rasa perusahaan seperti itu sudah termasuk perusahaan yang sanggup menerapkan kebijakan itu, walau tentu saja ada banyak juga perusahaan besar lainnya yang bisa."

Dalam sistem pengkaryaan kembali pekerja senior pekerja senior, perusahaan menerapkan sistem kerja kontrak untuk pekerjanya, sistem kontrak yang diberikan adalah sistem kontrak pertahun. Lalu meskipun pemerintah menghimbau untuk mengkaryakan pekerja senior setidaknya hingga usia 65 tahun, namun ada pula perusahaan yang terus mengkaryakan pekerja seniornya selama mugkin. Selama pekerja senior pasca pensiun itu masih mampu untuk bekerja.

KY mengatakan bahwa:

“..sebagian besar dari mereka ( perusahaan) memiliki sistem yang sama, mereka mengikuti peraturan orang Jepang dan pemerintah Jepang. (menurut) hukum ketenagakerjaan usia 60 tahun adalah usia wajib pensiun tapi hal tersebut kini diperpanjang menjadi 65 tahun. Dan setiap perusahaan memliki peraturannya sendiri dan kebanyakan dari perusahaan mengikuti peraturan Jepang" 


\section{3) Produktivitas Perusahaan}

Telah dibahas pada bab sebelumnya bahwa perusahaan manufaktur adalah jenis suatu perusahaan yang bekerja di bidang pembuatan atau pengolahan bahan mentah menjadi bahan jadi. Beberapa contoh perusahaan manufaktur misalnya perusahaan yang membuat mesin beserta peralatan atau onderdilnya, perusahaan tekstil, perusahaan makanan dan masih banyak lagi contoh yang lain. Perusahaan yang bergerak di jenis pekerjaan seperti ini disamping mengutamakan perolehan keuntungan juga dalam proses produksinya sangat mengandalkan penguasaan teknik, ide, dan memperhatikan detail dalam membuat produk-produk mereka.

Berikut penjelasan KY tentang pentingnya keahlian dalam perusahaan jenis manufaktur:

"Perusahaan kami adalah perusahaan manufaktur, sebuah perusahaan yang memproduksi sabuk transmisi, membuat produk untuk sepeda motor dan mesin-mesin lainnya. Dan teknik, mekanik sangat penting, desain-desain dan produk kami terdiri dari 4 jenis material yang berbeda, yang penting adalah mendesain, juga mengukur dimensi (ukuran luas maupun besar).Jadimembutuhkan keahlian untuk mengerjakannya..baik dalam membuat produk juga dalam produksihanya dibutuhkan keahlian ..."

Penyataan yang lebih kuat dikemukakan oleh $\mathbf{M}$

"Kami ingin mempekerjakan teknisi kami sedapat mungkin lebih lama lagi karena teknisi muda (diperusahaan jumlahnya) sedikit"

Bagi perusahaan $\mathbf{M}$, ketika di tanya keahlian apa yang sangat penting untuk perusahaan dan sejauh mana keahlian tersebut berpengaruh pada aktivitas perusahaannya, M menjawab bahwa yang paling penting adalah penguasaan pekerja akan keahlian memproses lembaran logam ataupun baja dengan teknik mengelas dan mengepres (menekan).Dalam perusahaan manufaktur KY yang paling penting adalah memaksimalkan waku produksi dengan memegang prinsip 2S yakni Seiri dan Seiton. Seperti yang dijelaskan di atas Seiri adalah memilah-milah barang yang dibutuhkan dan yang tidak dibutuhkan. Sedangkan Seiton adalah menyimpan barang-barang yang dibutuhkan sesuai dengan posisinya masingmasing. Kedua prinsip ini sangat berguna dalam menghemat waktu kerja, karena bagi mereka waktu adalah uang sehingga membuang waktu sama dengan membuang uang. Jika dalam perusahaan tidak menerapkan Seiri maupun Seiton maka barang-barang akan berantakan dan tidak pada tempatnya. Akibatnya dibutuhkan waktu yang lama untuk menemukan dan mengambil barang-barang yang dibutuhkan ketika produksi. Dan pekerja senior mempunyai kemampuan dalam menerapkan Seiri dan Seiton tersebut.

\section{4) Transfer Keahlian}

Dalam perusahaan manufaktur Jepang, selain penting untuk menjaga produktifitas demi tercapainya target perusahaan, penting pula menjaga terjaganya sumber daya manusia maupun teknologi dengan kualitas yang baik yang dapat mempertahankan eksistensi perusahaan tersebut. Sumber daya manusia dalam hal ini adalah kemampuan dari para pekerja di perusahaan dalam menyelesaikan pekerjaan, masalah-masalah yang terjadi dan sebagainya. Di era globalisasi saat ini perusahaan-perusahaan harus berkompetisi dengan ketat, maka dari itu penting untuk mempertahankan pekerja-pekerja yang memiliki keterampilan dan keahlian yang dibutuhkan oleh perusahaan, termasuk pekerja senior yang telah bekerja puluhan tahun di perusahaan dan menguasai semua keahlian yang dibutuhkan dengan baik. Jika para pekerja senior tersebut tidak dikaryakan kembali oleh perusahaan maka dapat terjadi hal-hal yang dapat menghambat poduktifitas perusahaaan itu sendiri. 
M yang merupakan seorang manajer ketika ditanya bagaimana dampak ketidakhadiran pekerja senior dalam perusahaan mengatakan bahwa akibatnya adalah keahlian atau teknik tidak dapat berlanjut serta tidak dapat membesarkan (mengajari) teknisi muda. Daripernyataan M di atas meski singkat, namun sebenarnya dapat menggambarkan hal yang sangat inti dalam perusahaan manufaktur Jepang. Sebagaimana telah dijelaskan sebelumnya bahwa yang paling penting dalam industri manufaktur adalah keahlian dan teknik, maka sudah menjadi keharusan bagi perusahaan untuk menjaga pekerja yang memiliki hal tersebut yakni pekerja senior jika tidak (seperti yang dikatakan oleh M), dampaknya seperti pernyataan di atas, perusahaan tidak dapat melestarikan ataupun mewariskan keahlian-keahlian yang dimiliki pekerja senior terhadap pekerja yang lebih muda sehingga dengan otomatis pekerja muda tidak dapat menerima keterampilan dari para pekerja senior dan tidak bisa menjadi teknisi seunggul seniornya. Akibatnya sudah dapat diprediksi, kurangnya teknisi yang unggul dalam perusahaan manufaktur dapat menghambat proses produksi itu sendiri. KY juga mengatakan hal yang hampir sama bahwa pekerja senior di perusahaanya mengajar pekerja yang lebih muda.

Dalam perusahaan yang berbeda seperti KY, sistem OJT juga dilaksanakan (sistem OJT adalah sistem yang umum dilaksanakan pada perusahaan-perusahaan Jepang) di dalamnya, pekerja senior yang memeiliki kompetensi tinggi mengajarkan hal-hal yang dibutuhkan perusahaan kepada pekerja yang lebih muda.

Setelah pemaparan di atas faktor ketiga fenomena pengkaryaan kembali senior pasca pensiun muncul adalah berasal dari kebutuhan perusahaan sendiri. Kondisi perusahaan Jepang yang bekerja pada bidang pekerjaan manufaktur menekankan pada produktifitas dan transfer keahlian. Produktivitas dalam menghasilkan barang merupakan nyawa bagi perusahaan manufaktur sehingga dibutuhkan orang-orang yang memilki keahlian untuk mengerjakan hal itu. Lalu dalam perusahaan jenis inipun pewarisan keahlian/ transfer keahlian menjadi hal yang telah dianggap tradisi dan tidak boleh tidak dilakukan, sebab regenerasi pekerja dalam perusahaan pasti terjadi yang mengharuskan keahlian diturunkan dari pekerja lama ke pekerja yang baru, jika tidak, hal tersebut bisa mengganggu produktifitas perusahaan tersebut. Di sini dapat terlihat perusahaan memiliki ketergantungan pada pekerja seniornya guna menunjang kegiatan inti perusahaannya.

\section{5) Gaji}

Faktor lain yang mempengaruhi dikaryakannya kembali pekerja senior pasca pensiun bagi perusahaan manufaktur sendiri adalah jumlah gaji yang diberikan. Status pekerja senior yang dikaryakan kembali setelah pensiun dalam perusahaan manufaktur Jepang adalah status pekerja kontrak. Kontrak bagi pekerja senior pasca pensiun adalah kontrak yang diperbaharui dengan melihat kondisi-kondisi tertentu, misalnya kesehatan dan kemampuan bekerja. KT mengatakan bahwa:

"Ya, sebenarnya usia wajib pensiun adalah umur 60 tahun. Satu tahun....satu tahun, tahun ke tahun kami memiliki kontrak tahunan, dan jika dia bekerja dengan baik maka dia akan dikontrak kembali di tahun berikutnya. (perusahaan) kami memiliki 5 kali kontrak. Hampir semua memiliiki sistem yang sama, mereka mengikuti peraturan pemerintah jepang. (menurut) Hukum ketenagakerjaan usia wajib pensiun adalah 60 tahun tapi saat ini usia itu diperpanjang hingga usia 65 tahun, jadi setiap perusahaaan memiliki peraturannya sendiri dan sebagian besar perusahaan mengikuti peraturan dari pemerintah.

Berdasarkan sistem yang diberlakukan pada pekerja senior yang dikaryakan setelah pensiun, yaitu sistem kontrak, secara logis dapat dikatakan bahwa terjadi perbedaan-perbedaan tertentu antara 
pekerja kontrak dan pekerja non-kontrak (tetap) dalam hal ini perbedaannya adalah gaji. Mengkaryakan kembali pekerja senior dengan sistem kontrak bagi perusahaan merupakan suatu benefit tersendiri maka hal ini juga menjadi salah satu alasan perusahaan mau mengkaryakan kembali pekerja seniornya yang telah pensiun.

Seperti yang dikatakan oleh KY, bahwa:

“.. dan juga jika (meskipun) gaji sedikit lebih rendah tetapi mereka tidak keberatan untuk bekerja. Karena program pensiun sebagian besar orang adalah pada usia 65 tahun (penerimaan uang pensiun)."

Kesimpulan yang dapat penulis peroleh dari faktor gaji ini adalah perusahaan memperoleh keuntungan dengan mengkaryakan kembali pekerja seniornya pasca pensiun, selain mereka membayar lebih rendah peekrjanya dari jumlah yang sebelumnya, mereka pun tetap dapat mempertahankan orang-orang yang mereka kehendaki untuk tetap berada di perusahaan, seperti para pekerja senior yang memang keahlian dan pengalamannya dibutuhkan untk mengajari pekerja yang lebih muda juga tetap bisa berkontribusi untuk menunjang produksi.

\section{6) Pandangan perusahaan terhadap pekerja muda}

Dewasa ini perkembangan teknologi melaju dengan pesat, Jepang sebagai salah satu negara maju terkenal dengan teknologinya yang mutakhir sehingga masyarakatnyapun tidak asing dengan kehadiran teknologi di sekitarnya, terlebih generasi mudanya yang justru terbiasa hidup dengan menggunakan teknologi. Namun dengan berkembangnya teknologi dan terbiasanya generasi muda Jepang saat ini dengan hal itu dalam aspek-aspek tertentu tentu membawa pengaruh tertentu pula, tidak terkecuali dalam perusahaan manufaktur.
Dalam perusahaan manufaktur yang terpenting adalah teknik, ide, dan detail. Hal tersebut sangat dibutuhkan dalam proses produksi sebagaimana yang perusahaan manufaktur geluti selama ini. Tanpa hal-hal tersebut, perusahaan tidak dapat berproduksi dan mencapai target-targetnya. Perkembangan teknologi dan terbiasanya generasi pekerja muda dengan teknologi memiliki pengaruh dalam membentuk kemampuan bekerja mereka khususnya untuk perusahaan manufaktur. Seperti yang dikatakan oleh KY dalam pandangannya terhadap pekerja yang lebih muda di perusahaannya bahwa:

$$
\text { "...budayanya berbeda. }
$$

Terdapat banyak perbedaan gap budaya. Karena masing-masing antara pekerja senior dan pekerja yang lebih muda beda budaya, beda generasi. Dan di Jepang kaum muda memiliki jalan pikir yang sangat berbeda dari yang lebih tua, mereka saat ini sangat familiar dengan sistem komputer, iphone, dan sebagainya...teknologi."

Menurut KY, antara pekerja senior dan pekerja yang lebih muda terdapat keadaan yang membuat mereka berbeda budaya maupun pola pikir dikarenakan oleh perbedaan generasi. Di zaman sekarang generasi muda Jepang lebih dekat dengan berbagai benda yang berbau teknologi. Hal ini mengindikasikan bahwa seiring perkembangan zaman dan kehidupan masyarakat membawa pengaruh terhadap perbedaan pola pikir dan minat antara pekerja senior dan pekerja junior. Hal ini seperti yang telah dijelaskan Giddens dalam teori perubahan sosial menegenai faktor globalisasi yang dampaknya mendunia. Proses globalisasi mendorong suatu masyarakat meningkatkan teknologinya.

Jepang adalah salah satu negara yang tidak diragukan lagi keunggulan perkembangan teknologinya. Teknologi Jepang sudah merambah hampir di seluruh dunia dan dikenal dalam pasar-pasar negara berkembang. Perkembangan teknologi dalam masyarakat Jepang semakin memudahkan 
berubah-sesuatu memang terjadi namun ia tak menemukan jawabannya, ia tidak tahu-menahu. (Tapi) Pekerja seniorlah yang akan menjawabnya"

Menurutnya kelebihan dari pekerja senior adalah mereka dapat memecahkan masalah dengan efektif dan mudah karena berkecimpung langsung di lapangan yaitu di lantai produksi, sementara bagi pekerja yang lebih muda dengan gaya bekerja yang berbeda seperti di atas, kemampuan itu tidak ada.

\section{Simpulan}

Setelah pemaparan pada bagian sebelumnya, penulis menyimpulkan bahwa kebijakan pengkaryaan kembali pekerja senior pasca pensiun oleh perusahaanperusahaan manufaktur di Jepang memperoleh dukungan atau dipandang positif dengan alasan sebagai berikut; 1) Angka harapan hidup yang semakin meningkat, 2) Adanya himbauan pemerintah Jepang untuk mengkaryakan kembali pekerja senior pasca pensiun, 3) Produktivitas perusahaan 4) Transfer keahlian, 5) Gaji yang tidak tinggi dan 6) Pandangan perusahaan terhadap pekerja muda yang berbeda keahlian dengan pekerja senior.

Sebuah perubahan yang terjadi pada masyarakat Jepang saat ini yakni memunculkan kebijakan pengkaryaan kembali pekerja senior pasca pensiun di perusahaan-perusahaan manufaktur berangkat dari beragam faktor yang cukup kompleks dari tubuh masyarakat Jepang sendiri. Penulis berkesimpulan bahwa kebijakan yang diambil pemerintah sebagai salah satu faktor pendorong perusahaan manufaktur mengkaryakan kembali pekerjanya adalah kebijakan solutif yang dapat menyelesaikan permasalahan para pekerja senior, perusahaan manufaktur dan negara Jepang.

\section{Daftar Pustaka}

Cabinet Office of Japan. (2005). Annual Report onThe Japanese Economy and Public Finance- No Gains Without Reforms $V$.

Giddens, Anthony. (2009). Sociology $6^{\text {th }}$ Edition. New York. Polity Press.

Yamamoto, Isamu (2003) 'Essay on The Retirement of Older Man in US and Japan'.

Kamus Online. Pengertian Manufaktur www.businessdictionary (manufacturing)

Yoshikawa, Hiroshi. (2002) Japan's manufacturing and non manufacturing Industries

Kawaguchi,Daiji.(2013) http://www.rieti.go.jp/en/papers/con tribution/kawaguchi/04.html.

Persentasi jumlah pekerja pada industrimanufaktur Jepang tahun 1975-2010.

https://research.stlouisfed.org/fred2/series/J PNPEFANA. 